\title{
Early Cases of Duodenal Carcinoma Invading the Portal Tract In The 1870s
}

\author{
Wilson IB Onuigbo* \\ Department of Pathology, the Medical Foundation \& Clinic, Africa
}

Received: February 28, 2018; Published: March 15, 2018

*Corresponding author: Wilson IB Onuigbo, Department of Pathology, The Medical Foundation \& Clinic, 8 Nsukka Lane, Enugu 400001, Nigeria, Africa, Tel: 2348037208680; Email: wilson.onuigbo@gmail.com

\author{
Abstract \\ Willis, in his famous book, wrote that Vogel was the first in 1891 to describe cancerous invasion of the portal tract. Therefore, this paper \\ sets out to provide the earlier dates of the 1870 s.
}

Keywords: Liver; POortal tract; Duodenum; Metastasis; History

\section{Introduction}

Willis, in his far famed "The Spread of Tumours in the Human Body," in 1973, mentioned that Vogel was the first to describe cancerous spread to the portal tract [1]. Therefore, since it is necessary to identify historical errors [2], any previous account should be documented.

\section{Historical Text}

Coupland [3], in 1879, described a typical case. The patient was a 80-year-old bookmaker, who stated on September 25th, 1879, that he suffered from pain and tenderness in the right hypochondria. There was increasing feebleness; jaundice supervened. The citrus deepened. At his death, the liver was much enlarged and olivegreen in color. The first part of the duodenum was cancerous. A bristle was passed through the pancreatic duct into the duodenum and the common bile duct. Growths were found to have occluded and invaded the hepatic ducts. Interestingly, that author added that his case resembled somewhat another one published in 1873 [4]. In comparison, the age was added as 72 years.

\section{Discussion}

Duodenal cancer is a relatively rare disease [5]. Because of their rarity, duodenal carcinomas are usually found in the literature as case reports [6]. From Hong Kong [7], Lee and his associates reported a 52-year-old man's case. Whipples operation was performed. The common bile duct, pancreas, stomach, and peritoneum were not affected. His post operative course was uneventful. In the experience of Bradford and his group from USA [8], "Many duodenal cancers are diagnosed at an advanced stage because symptoms of these cancers do not normally develop until the tumors have invaded adjacent structures, regional lymph nodes, or both." These observations are in keeping with the historical cases.

\section{References}

1. Willis RA (1973) The spread of tumours in the human body. London: Butterworths 29(329): 160.

2. Onuigbo WIB (1971) False firsts in cancer literature. Oncology 25: 163167.

3. Coupland S (1880) Carcinoma (medullary) of duodenum, just beyond pylorus, occluding and invading hepatic ducts. Trans Path Soc Lond 31: 130-135.

4. (1873) Anonymous. Trans Path Soc Lond 24: 103.

5. Ando T, Ishikawa T, Imamoto E, Kishimoto E, Suzuki K, et al. (2012) A case of inoperable duodenal cancer achieving long-term survival after multidisplinary treatment. Case Rep Gastroenterol 6(1): 111-117.

6. Adedeji AO, Trescoli-Serrano C, Garcia-Zarco M (1995) Primary duodenal carcinoma. Postgrad Med J 71: 354-358.

7. Lee CC, Ng WK, Lin KW, Lai TW, Li SM (2008) Adenocarcinoma of the duodenum. Hong Kong Med J 14: 67-69.

8. Bradford D, Levine MS, Hoang D, Rajeev M. Sachdeva, Eugene Einhorn et al. (2000) Early duodenal cancer: Detection on double-contrast upper gastrointestinal radiography. Am J Radio 174: 1564-1566. 


\section{(c) (i) This work is licensed under Creative}

Submission Link: https://biomedres.us/submit-manuscript.php

\begin{tabular}{ll} 
BIOMEDICAL & Assets of Publishing with us \\
RESEARCHES & - Global archiving of articles \\
& - Immediate, unrestricted online access \\
\hline
\end{tabular}

